\title{
Should equivocal Bordetella pertussis PCR results in children be reported to public health?
}

\author{
M Desjardins ${ }^{1,3}$, S Mousseau², P Doyon-Plourde ${ }^{3,4}$, N Brousseau ${ }^{5}$, D lachimov ${ }^{4}$, F Rallu ${ }^{3,6}$, \\ C Quach ${ }^{3,4,6,7 *}$
}

\begin{abstract}
Introduction: Real-time polymerase chain reaction (PCR) is the preferred method for the diagnosis of pertussis. In Quebec, positive and equivocal results are reportable to public health; in contrast, in Ontario equivocal results are not reportable.
\end{abstract}

Objective: To determine the clinical significance of equivocal, compared with positive results, in children with suspected pertussis.

Methods: Retrospective cohort of consecutive patients seen at the Centre Hospitalier Universitaire Sainte-Justine in Montréal, Quebec, with suspected pertussis and tested with a bacterial multiplex PCR (including Bordetella pertussis) between 2015 and 2017. Medical records were reviewed using a standardized form. Univariate analyses (Student's t-test and chi-square test) and multivariable logistic regression were used to compare cases of positive and equivocal results.

Results: Of the 1,526 multiplex PCR performed, 109 were positive and 24 equivocal. Both groups were similar in terms of demographics and disease severity assessments, but patients in the equivocal group had less paroxysmal cough (33.3\% vs $79.8 \%$, adjusted odds ratio [aOR] $0.11,95 \%$ confidence interval [CI] $0.04-0.29)$ and whoop ( $0 \%$ vs $18.3 \%, p<0.001)$, lower lymphocyte counts ( 6.6 vs $\left.11.9 \times 10^{9} / \mathrm{L}, p=0.008\right)$, were more likely to be diagnosed with a viral co-infection (16.7\% vs $3.7 \%$, aOR $5.62,95 \% \mathrm{Cl} 1.17-27.54)$ and were less likely to receive a macrolide ( $25 \%$ vs $89 \%$, aOR $0.04,95 \% \mathrm{Cl} 0.01-0.11)$. When admitted, patients with equivocal results had a shorter average length of stay ( 3.3 vs 12.2 days, $p=0.001$ ).

Conclusion: Although there were similarities in disease severity, children with suspected pertussis who had equivocal PCR results had significantly different clinical presentations compared with those with positive results. In the context of limited public health resources, these results may inform the decision whether or not equivocal results need to be reported to public health by laboratories.

Suggested citation: Desjardin M, Mousseau S, Doyon-Plourde P, Brousseau N, lachimov D, Rallu F, Quach C. Should equivocal Bordetella pertussis PCR results in children be reported to public health? Can Commun Dis Rep 2018;44(9):196-200. https://doi.org/10.14745/ccdr.v44i09a02

Keywords: pertussis, pediatrics, testing, equivocal results

\section{Introduction}

Pertussis is a highly contagious disease caused by Bordetella pertussis. Despite universal vaccination, pertussis still represents a major public health burden in Canada, particularly in children under the age of 15 years (1). Certain groups, such as infants, have an increased risk of severe disease. Pertussis cases are therefore reported to public health authorities within 48 hours of diagnosis, for epidemiological surveillance and contact management (2).

The clinical diagnosis of pertussis is challenging considering the wide spectrum of symptoms at presentation (3). Both nasopharyngeal culture and polymerase chain reaction (PCR) are accepted laboratory confirmation methods (4); however, given its increased sensitivity, PCR has become the preferred diagnostic method for pertussis in most provinces and territories $(2,5)$.

\section{Affiliations}

${ }^{1}$ Medical Microbiology and Infectious Diseases, Centre Hospitalier de I'Université de Montréal, Montréal, QC

2 Pediatric Emergency Division, Department of Pediatrics, Centre Hospitalier Universitaire SainteJustine, Montréal, QC

${ }^{3}$ Department of Microbiology, Infectious Diseases, and Immunology, Faculty of Medicine, University of Montréal, Montréal, $\mathrm{OC}$

${ }^{4}$ Research Institute, Centre Hospitalier Universitaire Sainte Justine, Montréal, QC

${ }^{5}$ Biological Risks and Occupational Health Division, Institut national de santé publique du Québec, Québec, QC

${ }^{6}$ Department of Medical Microbiology, Centre Hospitalier Universitaire Sainte-Justine, Montréal, QC

${ }^{7}$ Infection Prevention \& Control, Centre Hospitalier Universitaire Sainte-Justine, Montréal, QC

*Correspondence: c.quach@ umontreal.ca
The Centre Hospitalier Universitaire Sainte-Justine (CHUSJ), a pediatric tertiary care hospital in Montreal, uses an IS481-based real-time PCR for identification of $B$. pertussis. $\mathrm{PCR}$ is considered positive when cycle threshold $(\mathrm{Ct})$ is less than 36 and equivocal when $\mathrm{Ct}$ is 36-39.9. Currently, in Quebec, laboratories report equivocal results to public health authorities. These cases are investigated, including contact tracing, and interpreted according to clinical features (symptoms compatible with pertussis) and epidemiological information (history of contact) (2). In contrast, due to questions about the significance of equivocal results (5), Public Health Ontario determined that such results were not to be reported (6). Our study objective was to determine the clinical significance of an equivocal PCR result, when compared with positive PCR results, in children evaluated for suspected pertussis. 


\section{Methods}

\section{Study design}

This was a retrospective, observational cohort study of consecutive patients who were seen at CHUSJ for suspected pertussis and were tested with a bacterial multiplex PCR (B. pertussis, B. parapertussis, B. holmesii, Mycoplasma pneumoniae and Chlamydophila pneumoniae) between June 2015 and March 2017. The study protocol was approved by the CHUSJ's ethics committee.

\section{Study participants}

The overall cohort consisted of participants less than or equal to 17 years of age, with a bacterial multiplex PCR result available in the microbiology laboratory information system. Patients with a positive or equivocal PCR result for $B$. pertussis were included in our case series, regardless of where the test was ordered (emergency, ward, clinic, pediatric intensive care unit or neonatal intensive care unit). Patients not evaluated by a CHUSJ's physician on the day the test was performed were excluded, as data on their clinical presentation (symptoms and signs) were not available.

\section{Data collection}

Manual chart review of electronic medical records using Chartmaxx (Quest Diagnostics, Secaucus, New Jersey, United States [US]) was performed for all patients included in the cohort by two members of the research team (MD, DI). Data were extracted using a standardized case report form. Ten percent of charts were reviewed by both researchers to evaluate interrater agreement using kappa statistics. Collected data included demographic characteristics, past medical history and vaccination status, clinical presentation, disease severity and outcomes. When not recorded in the chart, specific signs and symptoms, as well as past medical history were considered absent. Disease severity was determined using two different severity scores: the Modified Preziosi Scale (MPS) and the Respiratory Severity Score (RSS). The MPS was used to measure pertussis severity in pediatrics. Severe disease is defined as a MPS greater than six (7). The RSS evaluates the severity of respiratory tract infections in pediatric patients. It was used to distinguish upper from lower respiratory infections and is correlated with the need for hospitalization (8). Because these two scores measure different constructs of respiratory infections, we compared both patients groups using the two scores.

\section{Data analysis}

Univariate analyses, using chi-square and Student's t-test as appropriate, were first performed to compare characteristics of patients with an equivocal (vs positive) result. Variables that were statistically significant upon univariate analysis, that were considered to be potential confounders based on the literature review, or had an impact on the model fit Akaike information criterion (AIC) were included in the multivariable logistic regression model (odds ratios - OR - and 95\% confidence intervals). All $p$ values were two-sided and considered significant at less than 0.05 (SPSS software, version 24, IBM Analytics, Armonk, New York US and R, version 3.4.3).

\section{Results}

A total of 1,526 consecutive bacterial multiplex PCR with available results, performed at CHUSJ between June 11, 2015 and March 31, 2017, were extracted from the laboratory information system. Of these, 109 patients tested positive for $B$. pertussis and 24 had equivocal results. The two groups were similar in terms of demographics (age, sex) and past medical history (history of asthma, prematurity), with the exception of a lower vaccination rate in those with a positive PCR (Table 1). The proportion of patients with a history of contact with a pertussis case was also similar.

Table 1: Patient demographic characteristics and past medical history

\begin{tabular}{|c|c|c|c|c|}
\hline Characteristics & $\begin{array}{c}\text { PCR } \\
\text { positive } \\
n=109(\%)^{a}\end{array}$ & $\begin{array}{c}\text { PCR } \\
\text { equivocal } \\
n=24(\%)^{a}\end{array}$ & $p$-value & $\begin{array}{c}\text { OR } \\
(95 \% \mathrm{Cl})\end{array}$ \\
\hline Age, mean (SD) & $6.65(5.35)$ & $6.26(5.23)$ & 0.75 & NA \\
\hline Male sex & $45(41.3)$ & $11(45.8)$ & 0.68 & $1.20(0.49-2.93)$ \\
\hline $\begin{array}{l}\text { Immunization up- } \\
\text { to-date }\end{array}$ & $79(72.5)$ & $22(91.7)$ & 0.046 & $4.18(1.13-27)^{b}$ \\
\hline Asthma & $16(14.7)$ & $7(29.2)$ & 0.09 & $2.39(0.82-6.56)$ \\
\hline Prematurity & $5(4.6)$ & $3(12.5)$ & 0.14 & $2.97(0.57-13.08)$ \\
\hline Immunosuppression & $0(0.0)$ & $0(0.0)$ & NA & NA \\
\hline $\begin{array}{l}\text { Contact with } \\
\text { pertussis case }\end{array}$ & $18(16.5)$ & $3(12.5)$ & 0.63 & $0.72(0.16-2.39)$ \\
\hline \multicolumn{5}{|l|}{ Patient location } \\
\hline Emergency & $89(81.7)$ & $16(66.7)$ & $0.10^{c}$ & $0.44(0.17-1.23)^{c}$ \\
\hline Ward & $14(12.8)$ & $7(29.2)$ & - & - \\
\hline Clinic & $5(4.6)$ & $1(4.2)$ & - & - \\
\hline $\mathrm{NICU}$ & $0(0.0)$ & $0(0.0)$ & - & - \\
\hline PICU & $1(0.9)$ & $0(0.0)$ & - & - \\
\hline \multicolumn{5}{|c|}{ Ordering physician specialty } \\
\hline Pediatric Emergency & $55(50.5)$ & $8(33.3)$ & $0.13^{d}$ & $0.49(0.19-1.21)^{d}$ \\
\hline Pediatrics & $43(39.4)$ & $12(50)$ & - & - \\
\hline Infectious Disease & $5(4.6)$ & $3(12.5)$ & - & - \\
\hline Family medicine & $6(5.5)$ & $0(0.0)$ & - & - \\
\hline Other specialty & $0(0.0)$ & $1(4.2)$ & - & - \\
\hline
\end{tabular}

Abbreviations: $\mathrm{Cl}$, confidence interval; $n$, number; NA, not applicable; NICU, neonatal intensive care unit; OR, odds ratio; $\mathrm{PCR}$, polymerase chain reaction; $\mathrm{PICU}$, pediatric intensive care unit; SD, standard deviation; "-", part of the above calculation

a With the exception of age which is reported as a mean and standard deviation

b Statistically significant results $(p<0.05)$

cEmergency vs other locations

${ }^{d}$ Pediatric Emergency vs other specialties

Signs and symptoms at laboratory and radiological investigations (paraclinical) performed are shown in Table 2. When comparing the two groups, there was no difference in terms of fever, rhinorrhea, cough, post-tussive vomiting, abnormal auscultation, wheezing, acute otitis media or pharyngitis. MPS scores were also similar in both groups. However, patients in the positive PCR group had significantly more paroxysmal cough, whoop, and lymphocytosis and less rhinorrhea and retractions than patients in the equivocal PCR group. In addition, there was no apnea reported in the latter group. Finally, patients with equivocal PCR tended to be more frequently tested for viral pathogens using a multiplex PCR (adjusted OR [aOR] 3.03 (0.82-11.35), with a greater proportion having a confirmed viral infection $(16.7 \%$ vs $3.7 \%$, aOR: $5.62,95 \% \mathrm{Cl}: 1.17$ to 27.54$)$. 
Table 2: Clinical presentation and investigations

\begin{tabular}{|c|c|c|c|c|c|}
\hline Presentation & $\begin{array}{c}\text { PCR } \\
\text { positive } \\
n=109(\%)^{a}\end{array}$ & $\begin{array}{c}\text { PCR } \\
\text { equivocal } \\
n=24(\%)^{a}\end{array}$ & $p$-value & $\begin{array}{c}\text { Crude } \\
\text { OR } \\
(95 \% \mathrm{Cl})\end{array}$ & $\begin{array}{c}\text { Adjusted } \\
\text { OR } \\
(95 \% \mathrm{Cl})\end{array}$ \\
\hline \multicolumn{6}{|c|}{ Clinical presentation } \\
\hline Fever & $10(9.2)$ & $5(20.8)$ & 0.10 & $\begin{array}{r}2.61 \\
(0.74-8.25)\end{array}$ & $\begin{array}{r}2.30 \\
(0.62-7.57)^{d}\end{array}$ \\
\hline Rhinorrhea & $31(28.4)$ & $12(50.0)$ & $0.04^{a}$ & $\begin{array}{r}2.52 \\
(1.02-6.26)^{\mathrm{a}}\end{array}$ & $\begin{array}{r}2.53 \\
(1.01-6.42)^{b, e}\end{array}$ \\
\hline Proven apnea & $10(9.2)$ & $0(0.0)$ & 0.12 & NA & NA \\
\hline $\begin{array}{l}\text { Length of } \\
\text { cough, days } \\
\text { (SD)c }\end{array}$ & $15.5(14.2)$ & $16.3(67.9)$ & 0.82 & NA & NA \\
\hline $\begin{array}{l}\text { Post-tussive } \\
\text { vomiting }\end{array}$ & $55(50.5)$ & $8(33.3)$ & 0.13 & $\begin{array}{r}0.49 \\
(0.19-1.21)\end{array}$ & $\begin{array}{r}0.49 \\
(0.19-1.21)^{\mathrm{e}}\end{array}$ \\
\hline $\begin{array}{l}\text { Paroxysmal } \\
\text { cough }\end{array}$ & $87(79.8)$ & $8(33.3)$ & $<0.001^{\mathrm{a}}$ & $\begin{array}{r}0.13 \\
(0.05-0.32)^{b}\end{array}$ & $\begin{array}{r}0.11 \\
(0.04-0.29)^{b, e}\end{array}$ \\
\hline $\begin{array}{l}\text { Whooping } \\
\text { cough }\end{array}$ & $20(18.3)$ & $0(0.0$ & $<0.001^{\mathrm{a}}$ & NA & NA \\
\hline $\begin{array}{l}\text { Abnormal } \\
\text { auscultation }\end{array}$ & $12(11.0)$ & $5(20.8)$ & 0.19 & $\begin{array}{r}2.13 \\
(0.62-6.49)\end{array}$ & $\begin{array}{r}2.18 \\
(0.60-7.19)^{\mathrm{e}}\end{array}$ \\
\hline Wheezing & $2(1.8)$ & $2(8.3)$ & 0.09 & $\begin{array}{r}4.86 \\
(0.56-42.34)\end{array}$ & $\begin{array}{r}3.38 \\
(0.36-31.52)^{f}\end{array}$ \\
\hline $\begin{array}{l}\text { Retractions } \\
\text { (any type) }\end{array}$ & $6(5.5)$ & $6(25.0)$ & $0.003^{\mathrm{a}}$ & $\begin{array}{r}5.72 \\
(1.62-20.29)^{b}\end{array}$ & $\begin{array}{r}5.61 \\
(1.55-20.76)^{b, g}\end{array}$ \\
\hline $\begin{array}{l}\text { Acute otitis } \\
\text { media }\end{array}$ & $5(4.6)$ & $3(12.5)$ & 0.14 & $\begin{array}{r}2.97 \\
(0.57-13.08)\end{array}$ & $\begin{array}{r}1.72 \\
(0.26-8.92)^{\mathrm{h}}\end{array}$ \\
\hline Pharyngitis & $9(8.3)$ & $1(4.2)$ & 0.49 & $\begin{array}{r}0.48 \\
(0.02-2.76)\end{array}$ & $\begin{array}{r}0.50 \\
(0.03-2.91)^{\mathrm{e}}\end{array}$ \\
\hline Cyanosis & $15(13.8)$ & $4(16.7)$ & 0.71 & $\begin{array}{r}1.25 \\
(0.33-3.90)\end{array}$ & $\begin{array}{r}0.69 \\
(0.13-3.16)^{f}\end{array}$ \\
\hline \multicolumn{6}{|l|}{ Severity score } \\
\hline MPS, mean & 5.7 & 4.8 & 0.31 & NA & NA \\
\hline $\begin{array}{l}\text { MPS, severe } \\
\text { disease }\end{array}$ & $30(27.5)$ & $6(25.0)$ & 0.80 & $\begin{array}{r}0.88 \\
(0.30-2.32)\end{array}$ & $\begin{array}{r}0.40 \\
(0.06-1.86)^{i}\end{array}$ \\
\hline RSS, mean & 0.5 & 1.3 & 0.07 & NA & NA \\
\hline \multicolumn{6}{|l|}{ Investigations } \\
\hline Viral PCR & $14(12.8)$ & $8(33.3)$ & 0.01 & $\begin{array}{r}3.39 \\
(1.19-9.33)\end{array}$ & $\begin{array}{r}3.03 \\
(0.82-11.35)^{f}\end{array}$ \\
\hline $\begin{array}{l}\text { Another virus } \\
\text { found }\end{array}$ & $4(3.7)$ & $4(16.7)$ & 0.02 & $\begin{array}{r}5.25 \\
(1.16-23.92)^{b}\end{array}$ & $\begin{array}{r}5.62 \\
(1.17-27.54)^{\mathrm{b}, \mathrm{e}}\end{array}$ \\
\hline $\begin{array}{l}\text { Lymphocytes } \\
\text { (x109/L), } \\
\text { mean (SD) }\end{array}$ & $11.9(10.9)$ & $6.6(2.8)$ & $0.008^{\mathrm{b}}$ & NA & NA \\
\hline $\begin{array}{l}\text { Pneumonia } \\
\text { on X-Ray }\end{array}$ & $5(4.6)$ & $2(8.3)$ & 0.46 & $\begin{array}{r}1.89 \\
(0.26-9.41)\end{array}$ & $\begin{array}{r}3.34 \\
(0.41-22.40)^{i}\end{array}$ \\
\hline
\end{tabular}

Abbreviations: $\mathrm{Cl}$, confidence interval; $\mathrm{n}$, number; NA, not applicable; MPS, Modified Preziosi Scale; OR, odds ratio; PCR, polymerase chain reaction; RSS, Respiratory Severity Score;

$\mathrm{SD}$, standard deviation

a All results reported as $n(\%)$ with the exception of length of cough (days) and lymphocytes,

which are reported as a mean with standard deviation, and MPS and RSS severity score, which are reported as a mean

Statistically significant results $(p<0.05)$

c Three missing data in each group

Adjusted for sex group and another virus found

e Adjusted for age

Adjusted for age and patient location

Adjusted for immunization up-to-date

Adjusted for age and another virus found

Adjusted for age, other virus found and patient location

Adjusted for age and immunization up-to-date

Patients' outcomes are presented in Table 3. Notably, patients in the equivocal PCR group were less likely to have a macrolide prescribed (aOR 0.04; 95\% Cl: 0.01 to 0.11 ), adjusting for age and presence of pneumonia on X-ray. In fact, only $25 \%$ of equivocal cases were treated for pertussis, despite having similar symptoms duration compared with patients in the positive PCR group. Moreover, despite a similar proportion of hospitalization in the two groups, patients with equivocal PCR had a shorter average length of stay, when admitted (3.3 vs 12.2 days, $p=0.001)$ and did not require intensive care admission.

\section{Table 3: Patients' outcomes}

\begin{tabular}{|c|c|c|c|c|c|}
\hline Outcomes & $\begin{array}{c}\text { PCR } \\
\text { positive } \\
n=109(\%)^{a}\end{array}$ & $\begin{array}{c}\text { PCR } \\
\text { equivocal } \\
n=24(\%)^{a}\end{array}$ & $p$-value & $\begin{array}{c}\text { Crude } \\
\text { OR } \\
(95 \% \mathrm{Cl})\end{array}$ & $\begin{array}{c}\text { Adjusted } \\
\text { OR } \\
(95 \% \mathrm{Cl})\end{array}$ \\
\hline $\begin{array}{l}\text { Received } \\
\text { amoxicillin }\end{array}$ & $0(0.0)$ & $4(16.7)$ & $<0.001^{b}$ & NA & NA \\
\hline $\begin{array}{l}\text { Received } \\
\text { macrolide }\end{array}$ & $97(90.0)$ & $6(25.0)$ & $<0.001^{b}$ & $\begin{array}{r}0.04 \\
(0.01-0.12)^{\mathrm{a}}\end{array}$ & $\begin{array}{r}0.04 \\
(0.01-0.11)^{\circ}\end{array}$ \\
\hline Hospitalization & $20(18.3)$ & $7(29.2)$ & 0.24 & $\begin{array}{r}1.81 \\
(0.63-4.83)\end{array}$ & $\begin{array}{r}4.63 \\
(0.75-47.96) \\
\end{array}$ \\
\hline $\begin{array}{l}\text { Length of stay, } \\
\text { mean (SD) }\end{array}$ & $12.2(10.2)$ & $3.3(1.0)$ & $0.001^{b}$ & NA & NA \\
\hline ICU stay & $7(6.4)$ & $0(0.0)$ & 0.20 & NA & NA \\
\hline Death & $0(0.0)$ & $0(0.0)$ & NA & NA & NA \\
\hline Return visits & $21(19.3)$ & $4(16.7)$ & 0.73 & $\begin{array}{r}0.82 \\
(0.22-2.45)\end{array}$ & $\begin{array}{r}0.81 \\
(0.22-2.45)^{c}\end{array}$ \\
\hline
\end{tabular}

Abbreviations: $\mathrm{Cl}$, confidence interval; ICU, Intensive Care Unit; n, number; NA, not applicable; OR, odds ratio; SD, standard deviation

With the exception of length of stay, which is reported as a mean and standard deviation

${ }^{b}$ Statistically significant results $(p<0.05)$

${ }^{c}$ Adjusted for age and pneumonia on X-ray

${ }^{d}$ Adjusted for age

\section{Discussion}

At CHUSJ, between June 2015 and March 2017, MPS and the RSS scores indicated that children with positive and equivocal $B$. pertussis PCR results showed certain similarities with respect to disease severity. However, there were many significant differences in terms of clinical presentations, paraclinical results and outcomes between the two groups. In fact, patients in the positive PCR group presented typical symptoms of pertussis, such as apnea, paroxysmal cough, post-tussive vomiting and whooping cough. The vast majority of positive cases were treated with a macrolide. In comparison, patients in the equivocal group presented more frequently with nonspecific upper respiratory tract infection symptoms such as rhinorrhea, fever, retractions and wheezing. In addition, the majority of patients with equivocal results were not treated with a macrolide, which suggests that the treating physician did not feel that treatment for pertussis was indicated.

Previously, using Ontario's reportable disease database, Bolotin et al. (5) also compared patients with positive and equivocal PCR results. They reported that patients with equivocal PCR results were less likely to be hospitalized than patients with positive PCR results, even if both groups were similar in terms of their clinical presentation. In our study, the two groups were significantly different with regards to their clinical presentations and outcomes, possibly because our population consisted of children, who are usually more severely affected by pertussis than adults. DeVincenzo et al. (9) also evaluated the relationship between PCR Ct value and pertussis severity. They showed that 
Ct values significantly correlated with length of hospitalization and lymphocytosis (9). Our results follow the same trend.

From an analytical point of view, many factors may explain differences found between patients with an equivocal and positive result. $B$. pertussis PCR target, IS481, is present in 50 to 200 copies/bacterial cell. It was previously shown that a PCR result with a $\mathrm{Ct}$ greater than 35 may represent the detection of less than one bacterium per sample (10). The significance of a late-cycle positive result remains thus uncertain. On the one hand, equivocal result may represent a true pertussis infection with a small bacterial load, as could be seen in the context of a disease lasting for more than three weeks, previous vaccination, partial immunity, or recent antibiotic use (2). In our study, the duration of symptoms was similar in the two groups, which makes the hypothesis of a longer lasting disease unlikely. Low-quality sampling could also result in equivocal results. On the other hand, equivocal results may be due to transient colonization in which $B$. pertussis is unrelated to the clinical syndrome. Waters et al. described an outbreak of atypical pertussis that occurred in Toronto in 2005-2006. Among 189 cases of pertussis, defined as PCR Ct value less than 40, only $42 \%$ met the clinical definition of pertussis and up to one third were positive for another respiratory pathogen. The mean $\mathrm{Ct}$ value for these cases was 38.41, from which arose the idea that some of these cases might represent transient colonization (11). Consequently, Papenburg and Fontela postulated an association between high $\mathrm{Ct}$ values and the presence of coinfection with respiratory pathogens (12). In our study, despite the fact that viral multiplex PCR was performed in a relatively low number of patients in the two groups, viral co-infections were four times more likely in patients with equivocal PCR results.

This large retrospective study evaluated consecutive children who were tested with a multiplex bacterial PCR for respiratory symptoms during a 22-month period in a tertiary care pediatric hospital in Montreal. One limitation of our study is the use of manual chart review for data collection, with hand-written notes that could have been interpreted differently by investigators. However, $10 \%$ of the charts were reviewed by two members of the team and inter-rater agreement was strong (kappa coefficient $=0.86$ ) (13). Another limitation is that this study was a single centre study; patients who were investigated at the CHUSJ could have consulted elsewhere for treatment in the days following their visit-these data would be impossible to capture. However, our case series describes $12.5 \%$ of all pertussis cases reported in the province of Quebec during the study period (14).

\section{Conclusion}

Although there were some similarities in terms of disease severity, children with suspected pertussis, who had equivocal PCR results, had significantly different clinical presentations compared with those with positive results. In the context of limited public health resources, these results may inform the decision whether or not equivocal results need to be reported to public health by laboratories.

\section{Authors' statement}

MD - conceptualization, methodology, validation, investigation, data curation, writing of original draft, review and editing of final version

SM - conceptualization, methodology, validation, investigation, review and editing of final version

PDP - formal analysis, review and editing of final version

NB - methodology, review and editing of final version

$\mathrm{DI}$ - investigation, data curation, review and editing of final version

FR - investigation, resources, review and editing of final version $\mathrm{CQ}$ - conceptualization, methodology, review and editing of final version, supervision, funding acquisition

\section{Conflict of interest}

None.

\section{Funding}

Dr. Quach is supported through an external salary award (FRQ-S merit, grant \# 252775).

This research was supported by the CHU Sainte-Justine Research Institute (C. Quach's start-up funds).

\section{References}

1. Douville-Fradet M, Amini R. Épidémiologie descriptive des maladies à déclaration obligatoire évitables par la vaccination au Québec, 2011-2013. Institut National de Santé Publique du Québec. 2016. www.inspq.qc.ca/sites/default/ files/publications/2198_maladies_evitables_vaccination_ declaration_obligatoire.pdf

2. Brousseau N, Judd L, Marcoux-Huard C, Landry M. Guide d'intevention - La coqueluche. Ministère de la santé et des services sociaux du Québec. 2017. http://publications.msss. gouv.qc.ca/msss/fichiers/2017/17-271-03W.pdf

3. Ebell MH, Marchello C, Callahan M. Clinical Diagnosis of Bordetella Pertussis Infection: A Systematic Review. J Am Board Fam Med 2017 May-Jun;30(3):308-19. https://doi. org/10.3122/jabfm.2017.03.160330. PubMed (https://www. ncbi.nlm.nih.gov/pubmed/28484063?dopt=Abstract)

4. Mattoo S, Cherry JD. Molecular pathogenesis, epidemiology, and clinical manifestations of respiratory infections due to Bordetella pertussis and other Bordetella subspecies. Clin Microbiol Rev 2005 Apr;18(2):326-82. https://doi.org/10.1128/ CMR.18.2.326-382.2005. PubMed (https://www.ncbi.nlm.nih. gov/pubmed/15831828?dopt=Abstract)

5. Bolotin S, Deeks SL, Marchand-Austin A, Rilkoff H, Dang V, Walton R, Hashim A, Farrell D, Crowcroft NS. Correlation of Real Time PCR Cycle Threshold Cut-Off with Bordetella pertussis Clinical Severity. PLoS One 2015 Jul;10(7):e0133209. https://doi.org/10.1371/journal. pone.0133209. PubMed (https://www.ncbi.nlm.nih.gov/ pubmed/26186564?dopt=Abstract)

6. Public Health Ontario. Bordetella testing by Real-Time PCR 2012. Toronto ON; Public Health Ontario: April 2012. 
www.publichealthontario.ca/en/eRepository/LAB_SD_078_ Bordetella_testing_real_time_PCR.pdf

7. Gill CJ, Mwananyanda L, MacLeod W, Kwenda G, Mwale M, Williams AL, Siazeeke K, Yang Z, Mwansa J, Thea DM. Incidence of Severe and Nonsevere Pertussis Among HIV-Exposed and -Unexposed Zambian Infants Through 14 Weeks of Age: Results From the Southern Africa Mother Infant Pertussis Study (SAMIPS), a Longitudinal Birth Cohort Study. Clin Infect Dis 2016 Dec;63(suppl 4):S154-64. https://doi. org/10.1093/cid/ciw526. PubMed (https://www.ncbi.nlm.nih. gov/pubmed/27838668?dopt=Abstract)

8. Feldman AS, Hartert TV, Gebretsadik T, Carroll KN, Minton PA, Woodward KB, Larkin EK, Miller EK, Valet RS. Respiratory Severity Score Separates Upper Versus Lower Respiratory Tract Infections and Predicts Measures of Disease Severity. Pediatr Allergy Immunol Pulmonol 2015 Jun;28(2):117-20. https://doi. org/10.1089/ped.2014.0463. PubMed (https://www.ncbi.nlm. nih.gov/pubmed/26155369?dopt=Abstract)

9. DeVincenzo JP, Guyton C, Rea H, Elmore E, Patel S, Wynn L, Harrison L, El Saleeby CM, Bagga B. Molecular detection and quantification of pertussis and correlation with clinical outcomes in children. Diagn Microbiol Infect Dis 2013 May;76(1):10-5. https://doi.org/10.1016/j.

diagmicrobio.2012.12.015. PubMed (https://www.ncbi.nlm.nih. gov/pubmed/23490009?dopt=Abstract)

10. Guthrie JL, Seah C, Brown S, Tang P, Jamieson F, Drews SJ. Use of Bordetella pertussis BP3385 to establish a cutoff value for an IS481-targeted real-time PCR assay. J Clin Microbiol 2008 Nov;46(11):3798-9. https://doi.org/10.1128/ JCM.01551-08. PubMed (https://www.ncbi.nlm.nih.gov/ pubmed/18784312?dopt=Abstract)

11. Waters $V$, Jamieson F, Richardson SE, Finkelstein $M$, Wormsbecker A, Halperin SA. Outbreak of atypical pertussis detected by polymerase chain reaction in immunized preschool-aged children. Pediatr Infect Dis J 2009 Jul;28(7):582-7. https://doi.org/10.1097/ INF.0b013e318197fac1. PubMed (https://www.ncbi.nlm.nih. gov/pubmed/19561423?dopt=Abstract)

12. Papenburg J, Fontela P. What is the significance of a high cycle threshold positive IS481 PCR for Bordetella pertussis? Pediatr Infect Dis J 2009 Dec;28(12):1143. https://doi.org/10.1097/ INF.0b013e3181bd4e1f. PubMed (https://www.ncbi.nlm.nih. gov/pubmed/19935278?dopt=Abstract)

13. McHugh ML. Interrater reliability: the kappa statistic. Biochem Med (Zagreb) 2012;22(3):276-82. https://doi.org/10.11613/ BM.2012.031. PubMed (https://www.ncbi.nlm.nih.gov/ pubmed/23092060?dopt=Abstract)

14. Ministère de la Santé et des Services sociaux. Vigie et surveillance des maladies à déclaration obligatoire d'origine infectieuse. Rapport annuel 2016. MSSS: 2017. http:// publications.msss.gouv.qc.ca/msss/fichiers/2017/17-268-05W. pdf

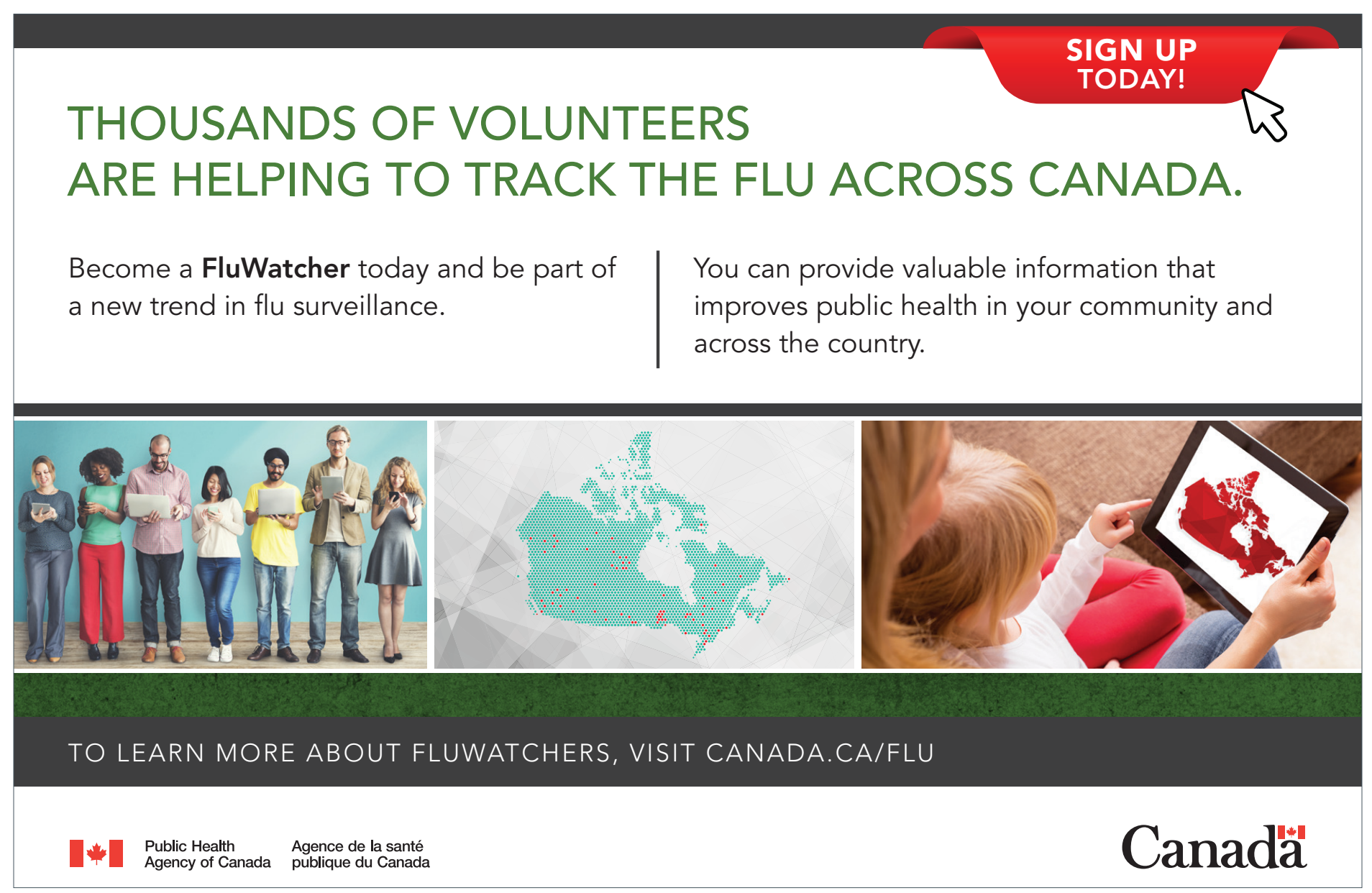

